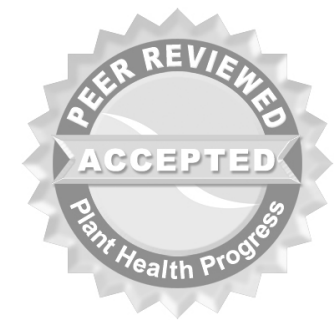

(c) 2008 Plant Management Network.

Accepted for publication 26 November 2007. Published 11 February 2008.

\title{
QoI Resistance of Plasmopara viticola and Erysiphe necator in the Mid-Atlantic United States
}

Anton Baudoin, Department of Plant Pathology, Physiology and Weed Science, Virginia Tech, Blacksburg 24061; Gilberto Olaya, Syngenta Crop Protection, Vero Beach, FL 32960;

François Delmotte, INRA, UMR Santé Végétale (INRA-ENITAB), Institut des Sciences de la Vigne et du Vin de Bordeaux, BP81-33883 Villenave d'Ornon Cedex, France; Jeneylyne F. Colcol, Department of Plant Pathology, Physiology and Weed Science, Virginia Tech, Blacksburg, 24061; and Helge Sierotzki, Syngenta Crop Protection, Stein, Switzerland

Corresponding author: Anton Baudoin. abaudoin@vt.edu

Baudoin, A., Olaya, G., Delmotte, F., Colcol, J. F., and Sierotzki, H. 2008. Qol resistance of Plasmopara viticola and Erysiphe necator in the mid-Atlantic United States. Online. Plant Health Progress doi: 10.1094/PHP-2008-0211-02-RS.

\section{Abstract}

Of 20 Plasmopara viticola isolates collected in four locations in Virginia and northwest North Carolina in 2005, 16 were resistant to Qol fungicides. The resistance factor was over 100, and label rates of formulated azoxystrobin and pyraclostrobin provided little or no control of these isolates. Additional sampling in 2006 revealed at least 15 additional vineyards with Qol-resistant P. viticola in Virginia, Maryland, and Pennsylvania. Of 22 isolates of Erysiphe (Uncinula) necator collected in 2005 from five Virginia locations, 20 isolates from 4 locations showed resistance to Qol fungicides. The G143A mutation for resistance was detected in several isolates of both pathogens. This is the first detection of this type of resistance in P. viticola in North America, and the second North American report of Qol resistance in $\mathrm{E}$. necator.

\section{I ntroduction}

Downy mildew (Plasmopara viticola) and powdery mildew [Erysiphe (Uncinula) necator] are common and serious diseases of vinifera and hybrid grapes in many viticultural areas. Since vinifera and many hybrid grape varieties are highly susceptible, control of these diseases is primarily accomplished through a program of fungicide applications. Because they are active against both diseases, QoI compounds, which include the strobilurins, have become a commonly used group since their worldwide introduction in 1996 and first availability in the USA in 1997. Four QoI fungicides have been registered for use on grapes in the USA. Of these, azoxystrobin (Abound) and pyraclostrobin (labeled for grapes in combination with boscalid in the package mix Pristine) are considered highly active against grape downy mildew, whereas kresoxim-methyl (Sovran) and trifloxystrobin (Flint) have lesser degrees of activity [e.g., (13)]. All four compounds have very good activity against grape powdery mildew, Erysiphe (Uncinula) necator.

Within a few years after the introduction of QoI compounds, practical resistance developed in some pathogens, such as cucurbit and cereal powdery mildew $(6,7)$. In Europe, QoI resistance in grape downy mildew was first observed in $2000(5,7,9,11)$, and has become common in many grape-growing areas [Fungicide Resistance Action Committee (FRAC) website, (4)]. QoI resistance is commonly conferred by a point mutation of the mitochondrial cytochrome $b$ gene that gives rise to a substitution from glycine to alanine at position 143 of the amino-acid sequence (G143A) and which can be detected by molecular methods $(2,7,8,11,12)$. However, before our preliminary report (1), 
such resistance had not previously been reported for P. viticola in North America. Grape powdery mildew resistance to QoI fungicides in New York and Pennsylvania was first reported by Wilcox et al. (14), and in 2006 was found for the first time in Europe, at a few locations in Hungary and Austria (4). Here we report the presence of QoI resistance in both grape downy and powdery mildew in Virginia since 2005.

\section{Downy Mildew}

In J uly 2005, a vineyard on Virginia's Eastern Shore (location A, Fig. 1) experienced an unexplained increase in grape downy mildew intensity, despite a spray program that included three Pristine (pyraclostrobin + boscalid) applications that would have been expected to provide excellent control of downy mildew. Four samples of downy mildew from different locations in this vineyard were obtained and established onto potted Vitis labrusca 'Catawba' plants, which were maintained in a greenhouse with low humidity to prevent uncontrolled sporulation. In a preliminary test, pyraclostrobin (Pristine) at $0.1 \mathrm{~g}$ ai/ liter and azoxystrobin (Abound) at $0.3 \mathrm{~g}$ ai/ liter (highest labeled per acre rate based on $100 \mathrm{gal} /$ acre or $935 \mathrm{liter} / \mathrm{ha}$ ) were applied to 'Catawba' plants. The plants were inoculated the following day with a bulk mix of the downy mildew isolates by spraying the abaxial leaf surfaces with a sporangial suspension of $10^{4}$ sporangia/ $\mathrm{ml}$. Plants were incubated overnight in a mist chamber, and held in a greenhouse until symptoms developed. Developing symptoms were confirmed to be of downy mildew by incubating leaves in moist plastic bags overnight to induce sporulation. Symptoms on azoxystrobin-treated plants were as severe as on non-treated control plants, whereas symptoms on pyraclostrobin-treated plants were slightly less extensive, but still substantial (Fig. 2).

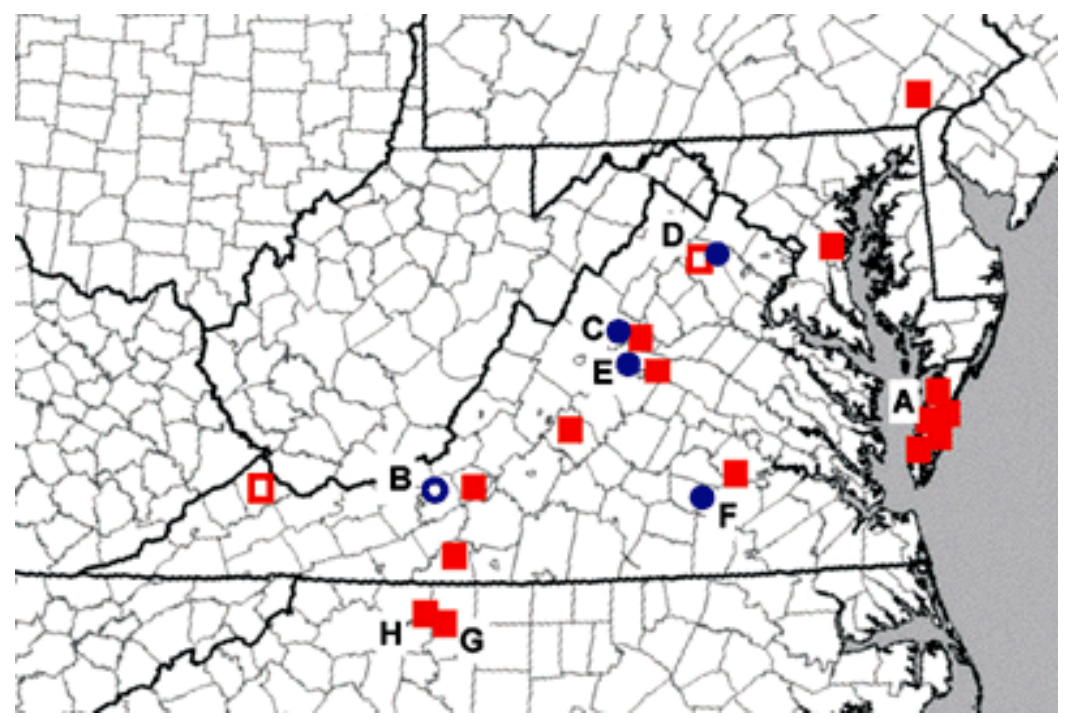

Fig. 1. Geographic origins of downy and powdery mildew isolates: Letters correspond to designations of 2005 isolates, red squares = downy mildew collections, blue circles $=$ powdery mildew collections, solid symbols $=$ isolate resistance to Qol fungicides, and open symbols $=$ Qol sensitivity. 


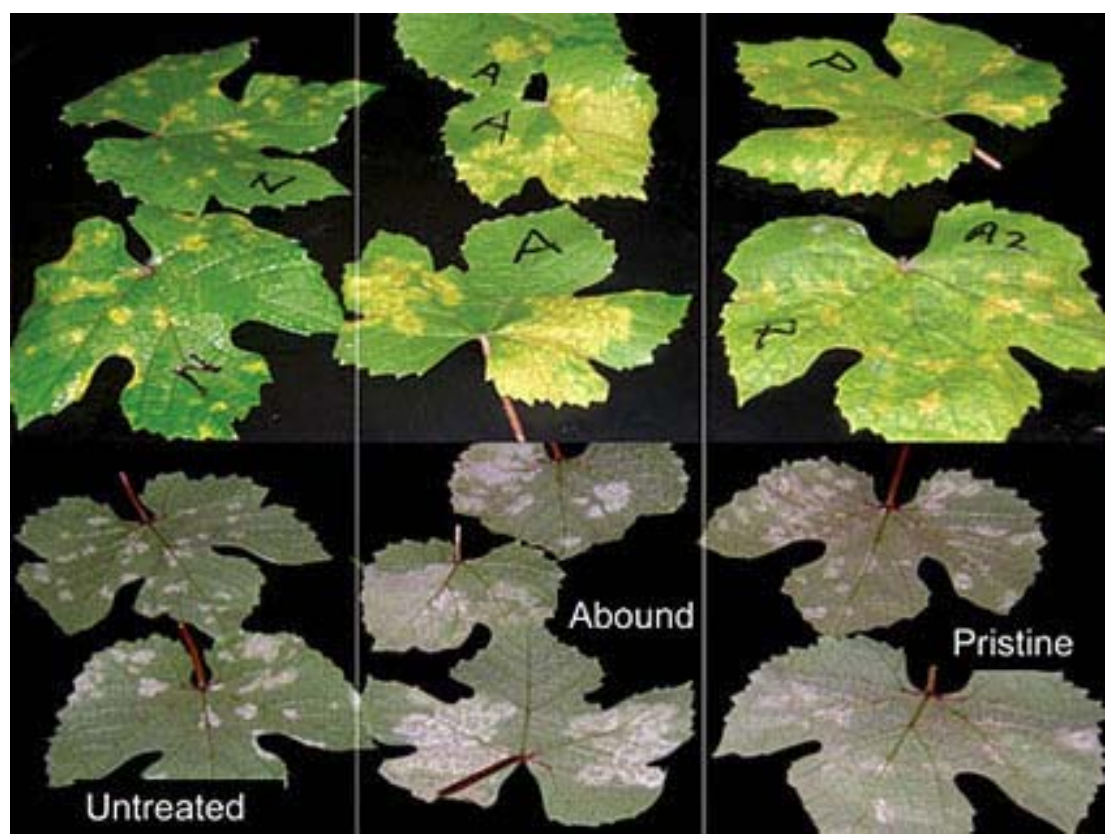

Fig. 2. Grape leaves treated with Abound, Pristine, or water (untreated) and inoculated with a bulk mix of Qol resistant P. viticola. Photo taken 10 days after inoculation.

P. viticola samples were obtained in August through October 2005 from two additional locations in Virginia and two vineyards near each other in northwest North Carolina (Fig. 1). Cultures were established on leaf discs of Vitis vinifera 'Chardonnay' or 'Riesling' on water agar in Petri dishes. Isolates were purified by transfer of single sporangiophores to fresh leaf discs, and were maintained subsequently by transfer every 2 to 3 weeks.

Small potted Riesling seedlings were sprayed with label rates (based on 100 $\mathrm{gal} /$ acre or $935 \mathrm{liter} / \mathrm{ha}$ ) of two compounds, each in two different formulations (Table 1). Cabrio, which consists of pyraclostrobin only, was included because of the possibility that the boscalid component of Pristine has some activity against downy mildew. Leaves were allowed to dry, and the following day the youngest fully expanded leaves were harvested and clipped into pieces of about $1 \mathrm{~cm}^{2}$, which were placed abaxial side up on water agar (15 g/liter) in 10-cm Petri dishes. They were inoculated with a drop of a sporangial suspension adjusted to 2 to $3 \times 10^{4}$ sporangia/ $\mathrm{ml}$, incubated overnight in the dark, and the drops were removed the following day. The dishes with leaf pieces were incubated under 12 $\mathrm{h}$ of light, and downy mildew development and sporulation were determined after 6 days. Both formulations of azoxystrobin and pyraclostrobin provided complete control of one isolate, but very little control of the other four isolates (Table 1).

Sensitivity of individual single-sporangiophore isolates to pyraclostrobin and azoxystrobin was determined by bioassay using leaf discs and methods adapted from those of Wong and Wilcox (15). Technical grade fungicide was dissolved in acetone, and dilutions in distilled water were prepared so that acetone concentration in the final dilution was less than 0.5\%. Leaf discs (13-mm diameter, cv 'Chardonnay') were soaked in dilutions of technical grade fungicide for $1 \mathrm{~h}$ with gentle agitation, blotted dry on clean paper towels, placed on water agar in Petri dishes, inoculated, and incubated as described above. 
Table 1. Downy mildew development on leaf pieces treated with several formulations of azoxystrobin and pyraclostrobin.

\begin{tabular}{|c|c|c|c|c|c|}
\hline \multirow{3}{*}{$\begin{array}{l}\text { Treatment } \\
\text { formulated product (ai) } \\
\text { Rate }\end{array}$} & \multicolumn{5}{|c|}{ I solate } \\
\hline & A-BA & A-22W & G-Gr1 & C-D1 & D-D2 \\
\hline & \multicolumn{5}{|c|}{$\begin{array}{l}\text { Percent downy mildew } \\
\text { incidence* }\end{array}$} \\
\hline $\begin{array}{l}\text { Abound ( } 249 \mathrm{~g} / \text { liter azoxystrobin) } \\
1.2 \mathrm{ml} / \text { liter }\end{array}$ & 65 & 74 & 64 & 75 & 0 \\
\hline $\begin{array}{l}\text { Heritage ( } 50 \% \text { azoxystrobin) } \\
0.66 \mathrm{~g} / \text { liter }\end{array}$ & 95 & 86 & 95 & 90 & 0 \\
\hline $\begin{array}{l}\text { Cabrio ( } 20 \% \text { pyraclostrobin) } \\
0.50 \mathrm{~g} / \text { liter }\end{array}$ & 52 & 59 & 61 & 77 & 0 \\
\hline $\begin{array}{l}\text { Pristine ( } 12.8 \% \text { pyraclostrobin + boscalid) } \\
0.79 \mathrm{~g} / \text { liter }\end{array}$ & 38 & 30 & 70 & 61 & 0 \\
\hline Control (water) & 88 & 82 & 94 & 100 & 88 \\
\hline
\end{tabular}

* Based on 17 to 23 leaf discs.

When grown on leaf discs treated with $1 \mathrm{mg} /$ liter azoxystrobin or pyraclostrobin, the $21 \mathrm{P}$. viticola isolates clearly separated into two groups (Table 2). Five isolates were strongly inhibited ( $<50 \%$ growth compared to the control at $1 \mathrm{mg} /$ liter azoxystrobin), whereas the other 16 displayed very little inhibition. The sensitivity ( $\mathrm{ED}_{50}$ for disease incidence, treatment concentration that caused 50\% inhibition based on the percentage of leaf discs with downy mildew) of sensitive isolates has been reported as 0.05 to $0.94 \mathrm{mg} /$ liter for sensitive isolates (15), and our isolates fell in this range. Several representatives of the 16 resistant isolates had ED50 values (incidence) near or over 100 $\mathrm{mg} /$ liter azoxystrobin, or approximately $25 \mathrm{mg} /$ liter pyraclostrobin (Table 3 ). Accurate determination of ED50 values of resistant isolates was hampered by the fact that high treatment concentrations of both azoxystrobin and pyraclostrobin sometimes caused extensive necrosis starting at the edges of leaf discs, a phenomenon observed by Wong \&Wilcox (15) for lower concentrations of kresoxim-methyl and trifloxystrobin, but not for azoxystrobin which was only tested at up to $8 \mathrm{mg} /$ liter.

Table 2. Reaction of P. viticola and E. necator isolates from several locations in Virginia and North Carolina (Fig. 1) to Qol fungicides.

\begin{tabular}{|l|l|c|c|c|c|c|}
\hline \multirow{2}{*}{\begin{tabular}{l} 
Code \\
\cline { 3 - 7 }
\end{tabular}} & $\begin{array}{l}\text { Source of } \\
\text { isolates }\end{array}$ & $\begin{array}{l}\text { Qol -resistant } \\
\text { in bioassay }\end{array}$ & $\begin{array}{c}\text { Presence } \\
\text { of G143A, } \\
\text { Syngenta PCR }\end{array}$ & $\begin{array}{c}\text { Presence } \\
\text { of G143A, } \\
\text { INRA PCR }\end{array}$ & $\begin{array}{c}\text { Qol-resistant } \\
\text { in bioassay }\end{array}$ & $\begin{array}{c}\text { Presence } \\
\text { of G143A, } \\
\text { Syngenta PCR }\end{array}$ \\
\hline A & Eastern Shore, VA & $4 / 4$ & $4 / 4$ & $4 / 4$ & - & - \\
\hline B & Blacksburgy & $0 / 1$ & 1 mixed/1 & $0 / 1$ & $0 / 2$ & $0 / 1$ \\
\hline C & Central VA & $3 / 3$ & $1 / 1$ & $3 / 3$ & $8 / 8$ & $0 / 1$ \\
\hline D & Northern VA & $0 / 3$ & $0 / 1$ & $0 / 3$ & $5 / 5$ & $1 / 1$ \\
\hline E & Central VA & - & - & - & $4 / 4$ & $1 / 1$ \\
\hline F & South-central VA & - & - & - & $3 / 3$ & $1 / 1$ \\
\hline G & Western NC & $2 / 2$ & $1 / 1$ & $2 / 2$ & - & - \\
\hline H & Western NC & $7 / 8$ & - & $7 / 8$ & - & - \\
\hline
\end{tabular}

$x$ Number of isolates growing well at $1 \mathrm{mg} /$ liter azoxystrobin/number of isolates tested.

y Downy mildew collected several years earlier and maintained in the greenhouse by repeated artificial inoculation. Powdery mildew from spontaneously propagating population on potted Chardonnay plants held outdoors. 
Table 3. Inhibition of downy mildew development of representative resistant isolates by several concentrations of azoxystrobin and pyraclostrobin.

\begin{tabular}{|c|c|c|c|c|c|c|}
\hline \multirow[b]{3}{*}{ Fungicide } & \multirow{3}{*}{$\begin{array}{l}\text { Rate } \\
\text { (mg/liter) }\end{array}$} & \multicolumn{5}{|c|}{ I solate } \\
\hline & & A- $22 W$ & A-BA & G-Gr1 & C-D1 & C-D2 \\
\hline & & \multicolumn{5}{|c|}{ Downy mildew incidence as \% of control* } \\
\hline \multirow[t]{3}{*}{ Azoxystrobin } & 50 & 94 & 80 & 89 & 100 & \\
\hline & 100 & 100 & 94 & 69 & 100 & \\
\hline & 200 & 92 & 87 & 100 & 100 & \\
\hline \multirow[t]{6}{*}{ Pyraclostrobin } & 25 & 50 & & 43 & 36 & \\
\hline & 50 & 0 & & 21 & 49 & \\
\hline & 100 & 9 & & 0 & 0 & \\
\hline & 10 & 94 & & 118 & & 100 \\
\hline & 20 & 96 & & 108 & & 100 \\
\hline & 30 & 50 & & 73 & & 50 \\
\hline
\end{tabular}

* Based on 15 to 21 leaf discs.

Additional sampling in J une to October of 2006 revealed that 84 of 88 new isolates with a response confirmed by repeated bioassay were QoI resistant. These isolates were from 15 additional vineyards in Virginia, Maryland, and Pennsylvania, with 10 of these vineyards (locations shown in Fig. 1) providing at least three isolates. A recent report from North Carolina (10) found that 19 of 20 vineyards tested in 2006 in that state had QoI-resistant P. viticola populations.

For the Syngenta PCR procedure, sporangia of six downy mildew isolates were collected and DNA was extracted using a DNeasy kit (Qiagen, Valencia, CA). The G143A single nucleotide polymorphism that leads to QoI resistance was assessed by ARMS-SYBR Green Q-PCR. The ARMS primer sequence for the wild type allele was 5' CCT TGG TGA CAA ATG AGT TTT TGG AG 3' and the sequence for the mutant allele was 5' CCT TGG TGA CAA ATG AGT TTT TGG AC 3'. The sequence of the common reverse primer was 5' CAA CTT CTT TTC CAA TTA ATG GGA TAG 3'. The PCR reaction mixture contained $5 \mu \mathrm{L}$ of DNA extract, $2.5 \mu \mathrm{L}$ of each primer, $2.5 \mu \mathrm{L}$ of water, and $12.5 \mu \mathrm{L}$ of $2 \times \mathrm{ABI}$ SYBR Mastermix (Applied Biosystems, Foster City, CA) containing sybr green, nucleotides, and the enzyme. The total volume of the PCR reaction was $25 \mu \mathrm{L}$. PCR reactions were performed in an ABI PRISM 7000 (Applied Biosystems, Foster City, CA). Reactions were performed using the following cycling profile: $95^{\circ} \mathrm{C}$ for $15 \mathrm{~min}, 40$ cycles of $94^{\circ} \mathrm{C}$ for $15 \mathrm{sec}, 60^{\circ} \mathrm{C}$ for $30 \mathrm{sec}$, and $72^{\circ} \mathrm{C}$ for $30 \mathrm{sec}$. Data collection was carried out during the $72^{\circ} \mathrm{C}$ step.

The PCR analysis detected the presence of the G143A mutation in all six of the P. viticola isolates tested that were not inhibited by QoI treatment in the leaf-disc bioassay (Table 2). The mutation was absent in one sensitive isolate, and results were mixed with a second isolate, which had been collected several years earlier and maintained in the greenhouse with no exposure to strobilurins. This isolate may have become contaminated with resistant isolates; it also produced some equivocal results in bioassays around this time; after purification by repeated transfer of single sporangiophores, it has been consistently sensitive and tested negative for G143A in subsequent PCR (see below).

A different PCR analysis was performed at INRA, Bordeaux. The G143A single nucleotide polymorphism (SNP) creates a recognition site of restriction endonuclease SatI that allows the quick characterization of QoI resistant isolates by Cleaved Amplified Polymorphism Sequence (CAPS) analysis. A 605 bp fragment of the cytochrome b gene (AY696297) was amplified using CB 279F (5'-TATACATATTTTTAGGGGTTTG-3') and CB 865R (5'-

ACATAGCGATAACACCACCAA-3') primers. The PCR was performed in $30 \mathrm{\mu l}$ volume containing $0.13 \mu \mathrm{M}$ of each primer, $0.2 \mathrm{mM}$ of each dNTP, $1 \times$ reaction

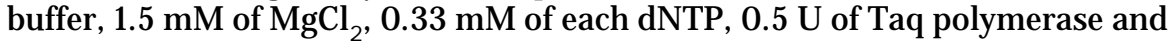


$1 \mu \mathrm{l}$ of genomic DNA. PCR cycles for the primer extension reaction consisted of $95^{\circ} \mathrm{C}$ for $4 \mathrm{~min}$ and $35 \mathrm{cycles}$ of $95^{\circ} \mathrm{C}$ for $45 \mathrm{sec}, 53^{\circ} \mathrm{C}$ for $50 \mathrm{sec}$ and $72^{\circ} \mathrm{C}$ for 1 min. Cleaving reactions were performed in a $10 \mu \mathrm{l}$ volume with $1.2 \mu \mathrm{l}$ of the PCR product, $1 \times$ buffer, and 1 U of SatI (5'-GCNGC-3'). Digestion was achieved at a temperature of $37^{\circ} \mathrm{C}$ with an incubation period of 2 hours. Digested PCR fragments were separated on a 1.5\% agarose gel and stained with ethidium bromide. PCR products of sensitive isolates yielded only one band (605 bp) whereas two digested DNA fragments (147 bp, $458 \mathrm{bp}$ ) were derived from QoI resistant isolates.

All 16 isolates resistant in bioassay had the G143A mutation, whereas this mutation was absent in 5 of 5 sensitive isolates (Table 2). Another mutation, F129L, has occasionally been found in QoI-resistant P. viticola (10); we did not test for its presence.

\section{Pow dery Mildew}

Twenty-two isolates of grape powdery mildew were obtained from four commercial vineyards in Virginia (Fig. 1), as well as from a few potted Chardonnay grape plants that had been maintained outdoors in Blacksburg, VA, for 6 years with a minimum of fungicide application [sulfur and occasional Rubigan (fenarimol), but no QoI applications].

Bioassay methods used were patterned after those of Wong and Wilcox (16). Leaf discs treated with fungicide as described for downy mildew were placed on water agar, adaxial side up, and inoculated with a single 1.3-mm-diameter glass bead dipped in $0.125 \mathrm{~g}$ Difco Bacto agar per $100 \mathrm{ml}$ water, and then touched to a sporulating powdery mildew colony. Colony diameters were measured after 6 to 12 days.

For PCR at Syngenta, the DNA of 5 powdery mildew isolates was extracted using the DNeasy kit (Qiagen, Valencia, CA). Single nucleotide polymorphism leading to the G143A change was assessed by ARMS-SYBR Green Q-PCR. The ARMS primer sequence for the wild type allele was 5' TAC GGG CAG ATG AGC CTA TGC GG 3' and the sequence for the mutant allele was 5' TAC GGG CAG ATG AGC CTA TGC GC 3'. The sequence of the common reverse primer was 5' ACC TAC TTA AAG CTT TAG AAG TTT CC 3'. The PCR reaction mixture contained $5 \mu \mathrm{L}$ of DNA extract, $2.5 \mu \mathrm{L}$ of each primer, $2.5 \mu \mathrm{L}$ of water, and $12.5 \mu \mathrm{L}$ of $2 \times$ ABI SYBR Mastermix (Applied Biosystems, Foster City, CA) containing sybr green, nucleotides, and the enzyme. The total volume of the PCR reaction was $25 \mu \mathrm{L}$. PCR reactions were performed in an ABI PRISM 7000 (Applied Biosystems, Foster City, CA). Reactions were performed using the following cycling profile: $95^{\circ} \mathrm{C}$ for $15 \mathrm{~min}, 40$ cycles of $94^{\circ} \mathrm{C}$ for $15 \mathrm{sec}, 60^{\circ} \mathrm{C}$ for $30 \mathrm{sec}$ and $72^{\circ} \mathrm{C}$ for $30 \mathrm{sec}$. Data collection was carried out during the $72^{\circ} \mathrm{C}$ step.

The response of the E. necator isolates to azoxystrobin also separated into two groups. Twenty of the 22 isolates tested in the leaf disc bioassay were found to be resistant to azoxystrobin (over $50 \%$ growth at $1 \mathrm{ppm}$, and most of these isolates grew well at 10 and $30 \mathrm{ppm}$ as well) (Table 2). PCR analysis detected the G143A mutation in 3 of 4 resistant isolates tested, but found it absent in one resistant and one sensitive isolate (Table 2). The response to pyraclostrobin, kresoxim-methyl and trifloxystrobin was not tested.

The G143A mutation has previously been found in a number of $E$. necator isolates collected in 2003 and 2004 from a suspected QoI-resistant vineyard population in New York [(3); H. Ypema, BASF, personal communication], and in a few locations in Hungary and eastern Austria (4).

\section{Spray History}

We collected spray records from most of the vineyards sampled in 2005 and some sampled in 2006. Despite some uncertainties, it appears that QoI fungicides were used (Fig. 1, Table 2) in vineyard A 12 times over 6 years; in location B, not a commercial vineyard, little or no exposure; in vineyard C 10 times over 5 years; in vineyard D 17 times over 7 years; in vineyard E, no record available due to changed management; in vineyard $\mathrm{F} 16$ or 17 applications over 5 years; and in vineyard G 9 times over 3 years. This averages to 2 to 3.4 applications per year, and is believed to be representative of common practice in 
Virginia; the maximum number of applications currently recommended by FRAC is 3 times per year, and labels allow 4 applications. Gullino (9) reported resistant $P$. viticola populations in Italian vineyards that had been treated 0 to 14 times with QoI materials. It appears that staying within FRAC recommendations has been insufficient to prevent the development of high resistance frequencies. Some evidence has been reported that QoI resistance in the absence of selection pressure (use of fungicides) tends to decline $(5,11)$, but it is unclear whether limiting use to, for example, one application per season would be able to restore the population to sensitivity.

\section{Conclusions}

QoI resistance in P. viticola has been reported in several European countries and at a Syngenta trial site in Brazil since 2000 (11), two years after widespread use of QoI fungicides commenced, but not previously in North America, where these compounds were introduced around the same time. Eighty-two isolates of P. viticola collected in 2000 and 14 in 2003 from the Finger Lakes region in New York were tested by Delmotte et al., but none carried the G143A mutation for QoI resistance [(3); F. Delmotte, unpublished results]. Our data show that QoI resistance in P. viticola is now widespread in the mid-Atlantic states. Growers should be very cautious in relying on QoI fungicides in or near vineyards with a history of regular use.

A possible reason for the delayed emergence of $\mathrm{P}$. viticola QoI resistance in eastern North America may be that the growing seasons of 1998, 1999, 2001, and 2002 were relatively dry, with many locations experiencing extended dry spells, whereas 2000, 2003, 2004, and the early part of 2005 tended to be wet and were characterized by frequent rains. The wet seasons of 2003 and 2004 may have allowed enough pathogen development and selection pressure to build up the frequency of resistance.

Grape powdery mildew resistance to QoI fungicides has been documented since 2002 in New York and Pennsylvania (14), and a few grape powdery mildew samples collected in 2002 from one Virginia vineyard with heavy use of QoI compounds were also QoI resistant (W. F. Wilcox, personal communication). In our 2005 samples, all four commercial Virginia vineyards sampled had QoIresistant populations, and ongoing research indicates that resistant populations are present in many additional vineyards.

\section{Acknowledgments}

The capable technical assistance by Sylvie Richard-Cervera (INRA) and Noemy Kraus (Syngenta) in the molecular characterization of pathogen isolates, by Moss Baldwin and Adrienne LaBranche (Virginia Tech) in performing bioassays, and support from the Virginia Wine Board, Viticulture Consortium East, and the Virginia Agricultural Council are gratefully acknowledged.

\section{Literature Cited}

1. Baudoin, A., and Baldwin, M. 2006. First report of QoI fungicide resistance of grape downy mildew in North America. (Abstr.) Phytopathology 96:S190.

2. Chen, W.-J ., Delmotte, F., Richard-Cervera, S., Douence, L., Greif, C., and CorioCostet, M.-F. 2007. At least two origins of fungicide resistance in grapevine downy mildew populations. Appl. Environ. Microbiol. 73:5162-5172.

3. FRAC. 2004. Intn'l FRAC QoI working group minutes 2004, non-cereal part: November 30th, 2004. Online. QoI Fungicide Meeting 2004. Fung. Resist. Action Committ.

4. FRAC. 2006. Intn'l FRAC QoI working group minutes 2006, non-cereal part: November 28th, 2006. Online. QoI Fungicide Meeting 2006. Fung. Resist. Action Committ.

5. Genet, J-L., J aworska, G., and Deparis, F. 2006. Effect of dose rate and mixtures of fungicides on selection for QoI resistance in populations of Plasmopara viticola. Pest Manag. Sci. 62:188- 194.

6. Gisi, U., Chin, K. M., Knapova, G., Küng Färber, R., Mohr, U., Parisi, S., Sierotzki, H., and Steinfeld, U. 2000. Recent developments in elucidating modes of resistance to phenylamide, DMI and strobilurin fungicides. Crop Prot. 19:863872. 
7. Gisi, U., Sierotzki, H., Cook, A., and McCaffery, A. 2002. Mechanisms influencing the evolution of resistance to Qo inhibitor fungicides. Pest Manag. Sci. 58:859867.

8. Grasso, V., Palermo, S., Sierotzki, H., Garibaldi, A., and Gisi, U. 2006. Cytochrome b gene structure and consequences for resistance to Qo inhibitor fungicides in plant pathogens. Pest Manag. Sci. 62:465-472.

9. Gullino, M. L., Gilarda, G., Tinivella, F., and Garibaldi, A. 2004. Observations on the behaviour of different populations of Plasmopara viticola resistant to QoI fungicides in Italian vineyards. Phytopathol. Mediterr. 43:341-350.

10. Ma, B., and Sutton, T. B. 2007. Study on QoI sensitivity of Plasmopara viticola causing grapevine downy mildew in North Carolina. (Abstr.) Phytopathology 97:S69.

11. Sierotzki, H., Kraus, N., Assemat, P., Stanger, C., Cleere, S., Windass, J ., and Gisi, U. 2005. Evolution of resistance to QoI fungicides in Plasmopara viticola populations in Europe. Pages 73-80 in: Modern Fungicides and Antifungal Compounds IV. H.-W. Dehne, U. Gisi, K. H. Kuck, P. E. Russell and H. Lyr, eds. Brit. Crop Prot. Counc., Alton, UK.

12. Sirven, C., and Beffa, R. 2003. Resistance to fenamidone: monitoring by real-time quantitative PCR on Plasmopara viticola. Planzenschutz-Nachrichten Bayer 56:523-532.

13. Weigle, T. H., and Muza, A. J . 2007. 2007 New York and Pennsylvania Pest Management Guidelines for Grapes. Online. IPM Guidlines For Pest Management. Cornell Univ. and Penn State Coop. Ext. Publ., Ithaca, NY.

14. Wilcox, W. F., Burr, J . A., Riegel, D. G., and Wong, F. P. 2003. Practical resistance to QoI fungicides in New York populations of Uncinula necator associated with quantitative shifts in pathogen sensitivities. (Abstr.) Phytopathology 93:S90.

15. Wong, F. P., and Wilcox, W. F. 2000. Distribution of baseline sensitivities to azoxystrobin among isolates of Plasmopara viticola. Plant Dis. 84:275-281.

16. Wong, F. P., and Wilcox, W. F. 2002. Sensitivity to azoxystrobin among isolates of Uncinula necator: Baseline distribution and relationship to myclobutanil sensitivity. Plant Dis. 86:394-404. 